\title{
Determination of optimum conditions for pectinesterase extraction from soursop fruit (Anona muricata) using response surface methodology
}

\begin{abstract}
Optimum conditions for the extraction of pectinesterase from soursop (Anona muricata) have been established. A fractional factorial design and response surface methodology was applied in this study, as a means of improving the method for developing an enzyme extraction procedure. Among the variables tested, $\mathrm{NaCl}$ and $\mathrm{pH}$ showed greater significant effects, while PVP, EDTA and incubation time seemed to have a lowering effect on the efficiency of pectinesterase extraction from soursop. The maximum enzyme extraction was obtained by using $1.92 \mathrm{M} \mathrm{NaCl}$ solution at $\mathrm{pH} 8.4$.
\end{abstract}

Keyword: Anona muricata; Pectinesterase extraction 